CORIGINAL ARTICLE

Volume 9 Issue 22017

DOI: 10.21315/eimj2017.9.2.3

ARTICLE INFO

Submitted: $17-05-2017$

Accepted: 31-05-2017

Online: 30-06-2017

\section{Does Study Skill Matter? A Descriptive Study on Undergraduate Health Profession Students in the University of the West Indies}

\author{
Niala Dwarika-Bhagat ${ }^{1}$, Bidyadhar Sa' ${ }^{1}$ Md. Anwarul Azim Majumder ${ }^{2}$ \\ ${ }^{1}$ The Faculty of Medical Sciences, The University of the West Indies; St. \\ Augustine, Trinidad $\mathcal{E}$ Tobago, WEST INDIES \\ ${ }^{2}$ Faculty of Medical Sciences, The University of the West Indies, Cave \\ Hill, Barbados, WEST INDIES
}

To cite this article: Dwarika-Bhagat N, Sa B, Majumder MAA. Does study skill matter? A descriptive study on undergraduate health profession students in the University of the West Indies. Education in Medicine Journal. 2017;9(2):27-40. https://doi.org/10.21315/eimj2017.9.2.3

To link to this article: https://doi.org/10.21315/eimj2017.9.2.3

\begin{abstract}
Introduction: Academic success requires students to evolve good study skills, time management and reducing distractions. As students in medical education are adult learners, it is expected that students need to be effective learners and should use self-directed strategy to find out the necessary information. Therefore, the teaching learning process in medical schools should encourage and motivate students to improve their self-directed capabilities. This body of research was conducted to identify the different study habits among students from five undergraduate health disciplines. Method: The Approaches and Study Skills Inventory for Students (ASSIST) questionnaire was administered to 367 students from five undergraduate health disciplines selected through convenient sampling. Results: The most popular definition of learning picked up by the respondents (73.3\%) was "able to use the information". Majority of the students were found to be strategic/deep learners. Male (vs. female students) and nursing students (vs. others) opted deep approach of learning. Students who are staying at home mainly used strategic/deep approach. Deep style was adopted least by the dentistry students, whereas the strategic style was used least by the veterinary students. One way ANOVA reveals that types of school in which the students are enrolled has significant effect on all the subscales of approach to studying either at 0.05 or 0.01 levels except "interest in ideas" and "organised studying". Conclusion: Students from different schools used varied approaches to their study and understanding of learning and as a whole student mainly adopted strategic and deep approaches. Students with a deep approach usually achieve a higher academic performance and motivating students towards a deep approach should be main aim of the medical science curricula. Further studies of learning styles in other medical schools in the Caribbean are required to examine whether there are specific benefits to particular styles for certain disciplines.
\end{abstract}

Keywords: Medical, undergraduate, deep approach, education, strategic approach, study approach, surface approach. 


\section{INTRODUCTION}

The drivers of effective learning among higher education students include academic environment, nature of the study materials, cognitive level of the learners, study skills of the students, and levels of students' motivation (1). The literature broadly refers to a student's approach to learning or "study skills/habits" as a student's knowledge and mastery of study strategies, management of time and other resources necessary to meet the demands of the academic curriculum. "Study habits typically denote the degree to which the student engages in regular acts of studying that are characterised by appropriate studying routines (e.g. review of material) occurring in an environment that is conducive to studying" (2).

Academic success therefore, logically requires students to evolve good study skills, leaving regular time to study and reducing distractions. According to Azikiwe (3), study habits are "the way and manner a student plans his or her private reading outside lecture hours in order to master a particular subject or topic."

Studies on students' approaches to learning are generally concerned with "cognitivefield approach" to human learning, placing emphasis on the "psyche" of the student and how the student devises his own approach to learning within the academic environment (4) but there exists literature which highlights disciplinary variation in students' approaches to learning (5). The literature relating to the typology of learning styles among undergraduate health professional students represents a comparatively small body of research. Chessell, Reid, et al. and McManus et al. (4, 6-7) investigated the deep, strategic and surface approaches to study and learning, which are influenced by undergraduate health professional students' perceptions of the learning environment. Research on clinical students in a UK medical school (7) highlighted that students who apply deep and strategic approaches to learning performed better in final examinations. In a similar vein,
McNulty et al. (8) compare findings on "rote" learning, "constructive" learning or "review learning" approaches and note that medical students choose between two learning styles: a deep approach whereby students are focused on understanding the meaning behind the assigned task or a surface approach where memorisation or rote-learning is preferred (4).

The positive and negative impact factors on student performance range from student characteristics, lifestyle, learning environments, instruction activities, students' academic ability prior to medical school, English language proficiency (9) study habits, study skills, and personal motivational factors (2). Even external motivational factors such as remuneration packages, family and job prospects (10) all drive a complex matrix affecting student performance. McNulty et al. (8) and Didarloo and Khalkhali (11) investigated the link between study habits and student performance in the basic science course in the USA and Iran respectively and found that study strategies were predominantly "rote" learning, "constructive" learning or "review learning" and poor to moderate study skills. The researchers noted that each strategy has its related study habit but that "constructive" learning reasoning were linked with higher academic performance. Both high and average GPA students showed no significant success traits as far as attendance at lectures, tutorials, practical sessions and clinical teachings; however those who attended problem-based learning classes had a higher GPA, suggesting that integration of new learning with existing knowledge solidifies student learning and performance (9). Research conducted by Amin et al. (10) with Singapore medical students reflected the students' view that lecturers should facilitate rather than impose learning, carefully explain the knowledge from the textbook and encourage students to think independently. While the actual learning experiences of health professional students have significant implications for teaching and learning within the academic 
environment, it is important to study the approaches to learning that underscore the learning experience (4). A study of undergraduate students at a Malaysian medical university (12) does present challenges these findings as it was found that these students' learning styles and approaches did not contribute significantly to their learning outcomes.

A number of instruments are used to assess students' approaches to study and the most widely used instruments include: Approaches and Study Skills Inventory for Students (ASSIST) (13), Visual, Aural, Read/Write, Kinaesthetic learningstyles inventory (VARK) (14), Motivated Strategies for Learning Questionnaire (MSLQ) (15), and Inventory of Learning Styles in Higher Education (ILS) (16).

The ASSIST which was developed by Entwistle and Ramsden provides a scoring structure that helps identify students at risk through ineffective study strategies (13). The instrument also analyse a student's characteristic orientation to studying as either "deep", "strategic" or "surface apathetic" approaches to learning. The student who applies the deep approach eliminates the habits and ideas which have made study unpleasant and burdensome, and take on new ones which make studying more pleasant and potentially productive (17). The deep approach is characterised by personal motivation and is consistently linked to academic success; students seek meaning in assignments and examinations, rely on evidence-based information, and integrate what they have learnt across the taught curriculum (12). Students who apply the strategic approach are organised, conscious of assessment demands, integrate ideas, practice good time management and monitor their own effectiveness while striving for higher goals. High scores is also a motivator for the student who employs the deep approach to learning (12). The surface apathetic approach is both characterised and restricted by a lack of purpose, rote learning, syllabus boundness, curriculum content overload and fear of failure and an overall intent to complete the assignment at hand $(6,12,18-20)$. Using the ASSIST scoring method, related literature concludes that the deep and strategic approaches have been consistently associated with academic success as opposed to the surface apathetic approach.

Therefore, we used the ASSIST to examine the following among the students of five undergraduate health disciplines of Faculty of Medical Sciences at the University of the West Indies, St. Augustine campus Trinidad and Tobago to:

1. Assess students' perception of learning

2. Assess students' learning approaches (deep, strategic, surface and apathetic approach)

3. To examine the main effect of gender on students' learning approach and its subscales

4. To examine the main effects of students' stay arrangements (hall, rented apartment and home) and the learning approach

5. To examine of interaction effect of gender and stay arrangements on the learning approach

6. To assess the effects of types of schools students were registered on learning approach

7. To assess students' preferences for different types of course and teaching

\section{METHODOLOGY}

\section{The Setting}

The University of the West Indies (UWI) was founded in 1948 in Jamaica, its first official title being the College of the University of London. At that time, 33 students from nine Caribbean countries were admitted to the newly established Faculty of Medicine. The UWI became an independent institution in 1962; two other campuses were established in Trinidad (1960) and Barbados (1963) respectively. 
In 1989, the Faculty of Medical Sciences (FMS) of the UWI was developed; it was a purpose-built facility located at the Eric Williams Medical Sciences Complex, Mt. Hope, Trinidad \& Tobago and its initial intake in 1989 was 50. The first schools of teaching were the School of Medicine, School of Dentistry, and School of Veterinary Medicine.

Growth has been phenomenal; compare the current intake of $250+$ for The School of Medicine and $300+$ for allied health programs. The faculty remains located in a pivotal regional health facility and today comprise five schools of learning - medicine, dentistry, veterinary medicine, pharmacy and nursing education (21).

The medical school adopted a ProblemBased Learning (PBL) curriculum and it is the only Caribbean medical school that currently offers this innovative learning modality. In the PBL environment, learning is student-centred and self-directed: students are given a medical problem to discuss, identify learning needs, and conduct further research; lecturers play a facilitating role in the process. Academic performance however, remains the formal yardstick that measures success and failure.

\section{Type of Research}

Cross-sectional

\section{Sampling and Study Population}

The questionnaire data was obtained over a period of one month and was obtained via questionnaires distributed one month prior to Semester 2 examinations. The distribution and collection of questionnaires was done face-to-face so as to ensure coverage across the five medical schools at the faculty. The responses on the selfcompleted questionnaires were of an anonymous nature.

The target population was the students in the Faculty of Medical Sciences distributed across all the five schools (School of
Medicine, School of Veterinary Medicine, School of Dentistry, School of Nursing and School of Pharmacy). A total of 367 students participated through non-random convenience sampling technique from all five schools.

\section{Ethical Approval}

Ethical approval for the study was granted by the Ethics Committee the University of the West Indies, St. Augustine Campus.

\section{Instrument}

The questionnaire - the short version of the Approaches and Study Skills Inventory for Students was used to collect data. The ASSIST (13) is a 64 -item self-report questionnaire, being an abbreviated version of Entwistle's 1970s 60-item Lancashire Approaches to Study self-reporting questionnaire in which items are divided into groups and assesses scores on five scales. This instrument has been applied, reviewed and validated in higher education settings that evaluate students' approaches to studying, study strategies and responses towards teaching (13). This approach provides the most specific data in relation to the factors underlying students' academic performance and also justifies the notion that "approaches to studying are a product of the interaction between the characteristics of individual student and their perceptions of courses, teaching and assessment procedures" (22).

The questionnaire spanned the following broad categories:

I. What is learning (focus is on the respondents views of learning and their rating in terms of how close they are to own way of thinking about it ranging from "5-Very Close" to "1Very Different"). The questionnaire contained three items consistent with a surface learning approach and three items consistent with a deep learning approach. 
II. Approaches to studying (focus is on the respondents real approach to studying). It comprises 52 questions and the psychometric scale ranges from "1-Disagree" to "5-Agree". The scores for sets of four questions are combined to yield 13 subscales to identify deep, strategic and surface approaches.

III. Preferences for different types of course and teaching (focus is on the respondents preference of course types and teaching methods). The questionnaire contained four items indicating a preference for courses and teaching that encourage surface learning and four items indicating a preference for courses and teaching that encourage deep learning. This psychometric scale ranges from "1-Definitely like" to "5-definitely dislike". Finally, the respondents were also asked to objectively rate their performance (grades obtaining) in the assessed work overall (on a 9 point scale stretching from very well (9) through rather badly (1)).

\section{Reliability of the Selected Instrument}

The Cronbach alpha $(\alpha)$ for the study habit instrument in the present study was found to be 0.86 ; which demonstrates a high level of reliability.

\section{Data Analysis}

The collected data was analysed using SPSS Version 19. The data from Section I (What is learning) and Section III (Preferences for different types of course and teaching) was treated with percentage for all students; and data from Section II (Approaches to studying) with regard independent effect of school/discipline was treated with one way and data for sex and stay arrangement was treated with two way ANOVA with post-hoc Tukey test.

\section{RESULTS}

\section{Demographic Characteristics of the Respondents}

The key characteristics of the respondents are presented in Table 1. Out of 367 students, there were 144 males (39.2\%) and 223 females $(60.8 \%)$. The highest number of respondents were from medicine $(48 \%)$ followed by veterinary schools $(21 \%)$. The findings also revealed that more than half of the respondents $(60.7 \%)$ stay at home. More female students $(38.4 \%)$ preferred to stay at home than their male counterpart $(22.3 \%)$.

Table 1: Characteristics of the respondents

\begin{tabular}{lc}
\hline \multicolumn{1}{c}{ Characteristics } & Respondents (\%) \\
\hline Gender & $144(39.2 \%)$ \\
Male & $223(60.8 \%)$ \\
Female & \\
Students from different schools & \\
Medicine & $176(48 \%)$ \\
Dentistry & $21(5.7 \%)$ \\
Nursing & $47(12.8 \%)$ \\
Pharmacy & $46(12.5 \%)$ \\
Veterinary & $77(21 \%)$ \\
Stay arrangements & \\
Hall at complex & $55(15 \%)$ \\
Rented apartment & $89(24.3 \%)$ \\
Home & $223(60.7 \%)$ \\
\hline
\end{tabular}

\section{Students' Perception of Learning}

When ask about the perception of learning (Table 2), the most popular definition of learning picked up by the respondents was "able to use the information" (73.3\%), followed by "building up knowledge with facts and information" (56.7\%), and "understanding new material" (56.1\%). "Seeing things in a meaningful way" (48.2\%), "developing as a person" (47.1\%) and "remember things well" (37.3\%) were the less popular definitions. For each definition identified, less than $5 \%$ of respondents recorded "rather different", "very different" or did not respond. 
Table 2: Students' perception of learning

\begin{tabular}{|c|c|c|c|c|c|c|}
\hline \multirow[b]{2}{*}{ What is learning? } & \multicolumn{6}{|c|}{ Respondents (\%) } \\
\hline & $\begin{array}{l}\text { Very } \\
\text { close }\end{array}$ & $\begin{array}{l}\text { Quite } \\
\text { close }\end{array}$ & $\begin{array}{l}\text { Not so } \\
\text { close }\end{array}$ & $\begin{array}{l}\text { Rather } \\
\text { different }\end{array}$ & $\begin{array}{c}\text { Very } \\
\text { different }\end{array}$ & $\begin{array}{l}\text { No } \\
\text { response }\end{array}$ \\
\hline Remember things well & $137(37.3 \%)$ & $157(42.8 \%)$ & $45(12.3 \%)$ & $15(4.1 \%)$ & $8(2.2 \%)$ & $5(1.4 \%)$ \\
\hline Developing as a person & $173(47.1 \%)$ & 145 (39.5\%) & $40(10.9 \%)$ & $5(1.4 \%)$ & $2(0.5 \%)$ & $2(0.5 \%)$ \\
\hline $\begin{array}{l}\text { Building up knowledge with } \\
\text { facts and information }\end{array}$ & $208(56.7 \%)$ & $135(36.8 \%)$ & $12(3.3 \%)$ & $5(1.4 \%)$ & $2(0.5 \%)$ & $5(1.4 \%)$ \\
\hline Able to use the information & $269(73.3 \%)$ & $81(22.1 \%)$ & $11(3 \%)$ & $4(1.1 \%)$ & 0 & $2(0.5)$ \\
\hline Understanding new material & 206 (56.1\%) & 120 (32.7\%) & $29(7.9 \%)$ & $9(2.5 \%)$ & 0 & $3(0.8 \%)$ \\
\hline $\begin{array}{l}\text { Seeing things in a meaningful } \\
\text { way }\end{array}$ & $177(48.2 \%)$ & $124(33.8 \%)$ & $55(15 \%)$ & $8(2.2 \%)$ & $1(0.3 \%)$ & $2(0.5 \%)$ \\
\hline
\end{tabular}

\section{Studying Approach to Study}

The scores for each studying approach of the students are shown in Table 3. According to the overall findings, majority of the students were found to be strategic/deep learners. There was a higher mean score for the deep approach in male compared to female students. Those students who are staying at home mainly used strategic/ deep approach than the students who were residing at hall complex and rented house. Nursing students preferred deep approach to studying than the students of other schools. It was also found that deep style was adopted least by the dentistry students, whereas the strategic style was used least by the veterinary students.

\section{Gender and Stay Arrangement, Types of School and on Study Habits}

The two way ANOVA analysis of main and interaction effects of gender and types of stay arrangement on sub-scales of study habits reveals that gender as a variable has significant effects on subscales "relating ideas" (df 1/361; $F=8.20$; $p<0.01)$; and "alertness to assessment" (df $1 / 361 ; F=4.22 ; p<0.05$ ); types of stay arrangements have significant effect on subscales "interest in ideas" ( $d f$ 2/361; $F=3.80 ; p<0.05)$; "deep approach" (df $2 / 361 ; F=3.90 ; p<0.05$ ) and the interaction effect on subscale "lack of purpose" (df $2 / 361 ; F=4.00 ; p<0.05)$.

Table 3: Students' approach to studying

\begin{tabular}{|c|c|c|c|c|c|c|c|c|c|c|}
\hline \multirow[b]{2}{*}{$\begin{array}{l}\text { Studying } \\
\text { approach }\end{array}$} & \multicolumn{2}{|c|}{ Gender } & \multicolumn{3}{|c|}{ Accommodation } & \multicolumn{5}{|c|}{ Schools } \\
\hline & $\begin{array}{c}\text { Male } \\
(n=144)\end{array}$ & $\begin{array}{c}\text { Female } \\
(n=223)\end{array}$ & $\begin{array}{l}\text { Hall at } \\
\text { complex } \\
(n=55)\end{array}$ & $\begin{array}{c}\text { Rented } \\
\text { apartment } \\
(n=89)\end{array}$ & $\begin{array}{c}\text { Home } \\
(n=223)\end{array}$ & $\begin{array}{l}\text { Medicine } \\
(n=176)\end{array}$ & $\begin{array}{l}\text { Dentistry } \\
(\mathbf{n}=21)\end{array}$ & $\begin{array}{l}\text { Nursing } \\
(n=47)\end{array}$ & $\begin{array}{c}\text { Pharmacy } \\
(n=46)\end{array}$ & $\begin{array}{c}\text { Veterinary } \\
(\mathbf{n}=77)\end{array}$ \\
\hline $\begin{array}{l}\text { Deep } \\
\text { approach }\end{array}$ & $\begin{array}{l}58.08 \pm \\
10\end{array}$ & $\begin{array}{l}57.07 \pm \\
9.63\end{array}$ & $\begin{array}{l}55.22 \pm \\
8.08\end{array}$ & $\begin{array}{l}56.1 \pm \\
10.05\end{array}$ & $\begin{array}{l}58.57 \pm \\
9.92\end{array}$ & $\begin{array}{l}58.23 \pm \\
9.77\end{array}$ & $\begin{array}{l}52.57 \pm \\
9.72\end{array}$ & $\begin{array}{l}60.06 \pm \\
11.02\end{array}$ & $\begin{array}{l}57.74 \pm \\
9.02\end{array}$ & $\begin{array}{l}55.3 \pm \\
8.78\end{array}$ \\
\hline $\begin{array}{l}\text { Strategic } \\
\text { approach }\end{array}$ & $\begin{array}{l}70.19 \pm \\
12.63\end{array}$ & $\begin{array}{l}73.15 \pm \\
12.14\end{array}$ & $\begin{array}{l}71.29 \pm \\
10.96\end{array}$ & $\begin{array}{l}69.88 \pm \\
12.17\end{array}$ & $\begin{array}{l}73 \pm \\
12.75\end{array}$ & $\begin{array}{l}70.91 \pm \\
12.71\end{array}$ & $\begin{array}{l}70.3 \pm \\
11.03\end{array}$ & $\begin{array}{l}76.09 \pm \\
12.65\end{array}$ & $\begin{array}{l}76.93 \pm \\
10.65\end{array}$ & $\begin{array}{l}69.44 \pm \\
11.70\end{array}$ \\
\hline $\begin{array}{l}\text { Surface } \\
\text { apathetic } \\
\text { approach }\end{array}$ & $\begin{array}{l}53.42 \pm \\
9.89\end{array}$ & $\begin{array}{l}52.94 \pm \\
10.12\end{array}$ & $\begin{array}{l}54.69 \pm \\
10.91\end{array}$ & $\begin{array}{l}52.54 \pm \\
10.33\end{array}$ & $\begin{array}{l}52.97 \pm \\
9.67\end{array}$ & $\begin{array}{l}51.26 \pm \\
9.36\end{array}$ & $\begin{array}{l}50.9 \pm \\
11.12\end{array}$ & $\begin{array}{l}51.26 \pm \\
10.90\end{array}$ & $\begin{array}{l}57.72 \pm \\
9.78\end{array}$ & $\begin{array}{l}56.39 \pm \\
9.24\end{array}$ \\
\hline
\end{tabular}


One way ANOVA reveals that types of school in which the students are enrolled has significant effect on all the subscales of approach to studying either at 0.05 or 0.01 levels except "interest in ideas" and "organised studying" (Table 4).

Further post-hoc Tukey test reveals that:

1. School of Nursing $(M=16.13)$ differs significantly from School of Medicine $(\mathrm{M}=14.48)$, School of Dentistry $(M=13.81)$, and School of Veterinary $(M=14.08)$ in subscale "seeking meaning" $(p<0.05)$

2. School of Medicine $(M=14.16)$ differs significantly from School of Dentistry $(M=11.52)(p<0.05)$

3. School of Nursing $(M=14.13)$ differs significantly from School of Dentistry $(M=11.52)$ in subscale "relating ideas" $(p<0.05)$

4. School of Nursing $(M=15.74)$ differs significantly from School of Dentistry $(\mathrm{M}=13.48)$ in subscale "use of evidence" $(p<0.05)$
5. School of Nursing $(M=60.06)$ differs significantly from School of Dentistry $(\mathrm{M}=52.57)$ in subscale "deep approach" $(p<0.05)$

6. School of Nursing $(M=14.87)$ differs significantly from School of Medicine $(M=12.95)$ and School of Veterinary $(\mathrm{M}=12.83)$ in subscale "time management" $(p<0.05)$

7. School of Pharmacy $(M=16.30)$ differs significantly from School of Medicine $(M=14.81)$ and School of Veterinary $(M=14.66)$ in subscale "alertness to assessment demands" $(p<0.05)$

8. School of Pharmacy $(M=16.83)$ differs significantly from School of Medicine $(\mathrm{M}=14.85)$ and School of Veterinary $(\mathrm{M}=14.65)$ in subscale "achieving" $(p<0.05)$

9. School of Dentistry $(M=14.29)$ differs significantly from School of Nursing $(\mathrm{M}=16.60)$ and School of Pharmacy $(\mathrm{M}=16.48)$ in subscale "monitoring effectiveness" $(p<0.05)$

Table 4: $F$ ratio showing independent effects of schools enrolled in on sub scales of study habits

\begin{tabular}{lccc}
\hline \multicolumn{1}{c}{ Sub scales of ASSIST } & $\boldsymbol{d f}$ & $\boldsymbol{F}$ & Level of sig. \\
\hline Deep approach & $4 / 362$ & 3.462 & .01 \\
Seeking meaning & $4 / 362$ & 4.647 & .01 \\
Relating ideas & $4 / 362$ & 4.278 & .01 \\
Use of evidence & $4 / 362$ & 2.857 & .05 \\
Interest in ideas & $4 / 362$ & 1.262 &. NS \\
Strategic approach & $4 / 362$ & 4.514 & .01 \\
Organised studying & $4 / 362$ & 1.425 & NS \\
Time management & $4 / 362$ & 4.227 & .01 \\
Alertness to assessment demands & $4 / 362$ & 2.885 & .05 \\
Achieving & $4 / 362$ & 5.192 & .01 \\
Monitoring effectiveness & $4 / 362$ & 3.426 & .01 \\
Surface apathetic approach & $4 / 362$ & 7.093 & .01 \\
Lack of purpose & $4 / 362$ & 3.300 & .05 \\
Unrelated memorising & $4 / 362$ & 3.843 & .01 \\
Syllabus -boundness & $4 / 362$ & 2.815 & .05 \\
Fear of failure & $4 / 362$ & 6.770 & .01 \\
\hline
\end{tabular}


10. School of Pharmacy $(M=76.93)$ differs significantly from School of Medicine $(M=70.91)$ and School of Veterinary $(M=69.44)$ and School of Nursing $(\mathrm{M}=76.09)$ differs significantly from School of Veterinary $(M=69.44)$ in subscale "strategic approach" $(p<0.05)$

11. School of Pharmacy ( $M=12.28)$ differs significantly from School of Medicine $(M=10.09)$ in subscale "lack of purpose" $(p<0.05)$

12. School of Pharmacy ( $M=14.07)$ differs significantly from School of Medicine $(M=12.43)$ and School of Nursing $(\mathrm{M}=12.34)$ in subscale "unrelated memorising" $(p<0.05)$

13. School of Veterinary $(M=16.71)$ differs significantly from School of Medicine $(M=14.89)$; School of Dentistry $(M=13.62)$ and School of Nursing $(M=12.34$; and School of Pharmacy $(M=16.24)$ differs significantly from School of Dentistry $(M=13.62)$ in subscale "fear of failure" $(p<0.05)$
14. School of Pharmacy $(M=57.72)$ differs significantly from School of Medicine $(M=51.26)$ and School of Nursing $(\mathrm{M}=51.26)$; School of Veterinary $(\mathrm{M}=56.39)$ differs significantly from School of Nursing $(M=51.26)$ and School of Medicine $(M=51.26)$ in subscale "Surface apathetic approach" $(p<0.05)$.

\section{Preferences for Different Types of Course and Teaching}

This section of the questionnaire requires that students express preferences for different types of course and teaching (Table 5). It was found that more than half of the respondents definitely liked lecturers who provided good notes $(51.5 \%)$, courses with defined reading lists $(56.7 \%)$, and books which provide definite facts and information to learn $(68.1 \%)$. Finally, when the respondents were asked to rate their performance in their assessed work on a 9 point scale, $63.6 \%$ reported that they were doing well in their assessed work.

Table 5: Preferences for different types of course and teaching approaches among respondents

\begin{tabular}{|c|c|c|c|c|c|c|}
\hline $\begin{array}{l}\text { Preferences for } \\
\text { different types of } \\
\text { course and teaching }\end{array}$ & $\begin{array}{l}\text { Definitely } \\
\text { like }\end{array}$ & $\begin{array}{l}\text { Like to } \\
\text { some extent }\end{array}$ & Unsure & $\begin{array}{l}\text { Dislike to } \\
\text { some extent }\end{array}$ & $\begin{array}{l}\text { Definitely } \\
\text { dislike }\end{array}$ & $\begin{array}{l}\text { No } \\
\text { response }\end{array}$ \\
\hline $\begin{array}{l}\text { Lectures which give } \\
\text { good notes }\end{array}$ & 189 (51.5\%) & $136(37.1 \%)$ & $19(5.2 \%)$ & $12(3.3 \%)$ & $8(2.2 \%)$ & $3(0.8 \%)$ \\
\hline $\begin{array}{l}\text { Lectures which challenge } \\
\text { to think }\end{array}$ & $182(49.6 \%)$ & $143(39 \%)$ & $21(5.7 \%)$ & $14(3.8 \%)$ & $5(1.4 \%)$ & $2(0.5 \%)$ \\
\hline $\begin{array}{l}\text { Exams which allow } \\
\text { students to think }\end{array}$ & $112(30.5 \%)$ & $156(42.5 \%)$ & $33(9 \%)$ & $53(14.4 \%)$ & $10(2.7 \%)$ & $3(0.8 \%)$ \\
\hline Exams linked to lectures & $172(47.4)$ & $138(37.6)$ & $16(4.4)$ & $27(7.4)$ & $6(1.6)$ & $6(1.6)$ \\
\hline $\begin{array}{l}\text { Courses with defined } \\
\text { reading lists }\end{array}$ & $208(56.7 \%)$ & $113(30.8 \%)$ & $20(5.4 \%)$ & $13(3.5 \%)$ & $9(2.5 \%)$ & $4(1.1 \%)$ \\
\hline $\begin{array}{l}\text { Courses which } \\
\text { encourage further } \\
\text { reading }\end{array}$ & $65(17.7 \%)$ & $125(34.1 \%)$ & $21(5.7 \%)$ & $113(30.8 \%)$ & 39 (10.6\%) & $4(1.1 \%)$ \\
\hline $\begin{array}{l}\text { Books which challenge } \\
\text { to study beyond the } \\
\text { lectures }\end{array}$ & $33(9 \%)$ & $60(16.3 \%)$ & $40(10.9 \%)$ & $60(16.3 \%)$ & $33(9 \%)$ & $4(1.1 \%)$ \\
\hline $\begin{array}{l}\text { Books which provide } \\
\text { definite facts and } \\
\text { information to learn }\end{array}$ & $250(68.1 \%)$ & $89(24.3 \%)$ & $10(2.7 \%)$ & $9(2.5 \%)$ & $4(1.1 \%)$ & $5(1.4 \%)$ \\
\hline
\end{tabular}




\section{DISCUSSION}

The key findings of the study was that majority of the students in the Faculty of Medical Sciences, UWI St. Augustine campus either use strategic or deep approaches of learning. The research also concluded that students from nursing and medicine adopt a deep approach than their counterparts in other allied health programs within the faculty. A number of factors influence effective learning of medical science students which help to apply theory to clinical practice (23-24). Learning approaches are found to be one of the most important factors for preparing medical science students for their future roles (25). In the literature, a number of different approaches to learning were mentioned for students to adopt (26). One of the most preferred styles of learning is deep learning. In the deep approach, an emphasis is placed on understanding concepts and relating ideas and information processed to a "deep" level is better retained than information processed only to a "surface" level. It was found that student-centered approach to teaching and learning in higher education context encouraged students towards a deeper approach to study (27). Rote learning is the typical surface approach (26). The strategic or achieving approach, is associated with assessment, specifically to obtain a high examination grade (28). Evidence demonstrated that both the deep and strategic approaches are more likely to result in success in final examinations in medical schools (29). It was also found that doctors who adopted a deep approach to learning were life-long learners and pursued additional postgraduate academic training later in their professional life than those who adopted a surface approach of learning (30).

Student learning styles and approaches using different questionnaire on medical (31), dental (32), nursing (33), pharmacy (34), health science (35) and veterinary (18) students were reported worldwide. To date, limited studies were conducted to investigate the effect of learning styles on the educational performance of medical science students in the Caribbean region. A study was conducted in the Xavier University School of Medicine, Aruba using the ASSIST questionnaire and found that students mainly used deep and strategic learning, which is also consistent with findings (36). Another study conducted in the Faculty of Medical Sciences at the University of the West Indies (UWI) St. Augustine campus using the ASSIST questionnaire to examine the motivational factors and approaches to learning of medical students identified that motivation to study was significantly and positively associated with deep and strategic approaches to learning and negatively associated with and surface approach to learning (37). Martin et al. (38) used a former VARK learning styles questionnaire and the Kurt Lewin Leadership Style model to determine the relationships between learning styles, leadership styles and Grade Point Average (GPA) of undergraduate engineering students of various faculties of the University of the West Indies, St. Augustine campus and reported no significant relationships between the students' learning styles, leadership styles, and their GPA (38).

Other key findings of the present study include that most of the students agreed upon the definition of learning of being able to use the information; it may be the reason that the students in the Faculty of Medical Sciences believe in the philosophy of practical and clinical application of acquired knowledge. Another finding showed that more than half of the respondents definitely liked lecturers who supplied the recommended books for the courses $(56.7 \%)$ and with definite facts and information $(68.1 \%)$. This finding may be attributed to exponential increase of biomedical knowledge and information and overwhelmingly and widely available information in the electronic and other media. Students may still be in a "spoonfeed" mood - a state to seek the meaningful and relevant information for their learning 
and examinations. As students in medical education are adult learners, it is expected that students need to be effective learners and should use self-directed strategy to find out the necessary information (24). The students must learn how to research and integrate relevant information to diagnose and treat patients' problems in the best possible way (39). Therefore, the teaching learning process in health profession schools should encourage and motivate students to improve their self-directed capabilities (40). It is a widely held view that student-centred approach (e.g. problem-based learning) promotes self-directed and deep learning in students (41).

The significant effect of gender on the ASSIST sub-scale of "relating ideas" in favour of male students $(\mathrm{M}=14.18)$ against female $(M=13.01)$ suggest that the male students are inclined to think and establish links among ideas. Further with regard to effect of gender on subscale "alertness to assessment" leans in favour of female students $(M=15.01)$; whereas male students are not so alert to assessments ( $M$ $=14.30)$. It may be because of the fact that female students focus on passing exams. Studies reported that female students in higher education were found to be more motivated for achievement, more disciplined to prepare themselves for exams as well as more responsible in their work (42).

It was also found that types of stay arrangements have significant effect on subscales "interest in ideas" (with Means; Hall $=13.35$, Rented apartment $=13.86$, and Home $=14.58$ ) and "deep approach" (with Means; Hall $=55.25$, Rented apartment $=56.17$, and Home $=58.74$ ) in favour of those who are staying at home versus their counterparts staying at rented apartments or halls. This may underscore the fact that students staying at home face less negative peer influences and more controlled parental/guardian atmospheres conducive to study. This is consistent with research evidence which points to positive parenting and parental support as driving students' academic achievement and adjustment. The Desforges Report (43) presented a comprehensive literature review on the topic of parental involvement, parental support and family education on student performance and found the relationship among the variables of people, processes and institutions, the positive impact of "at-home good parenting" on a student's academic progress spans social and ethnic groups.

The interaction effects of gender and stay arrangement suggest that female students staying at hall $(M=11.91)$ and rented apartments $(M=11.05)$ are found to lack purpose regarding the direction of their studies than when compared to their male counterparts staying at hall $(M=11.05)$ and rented apartment $(M=10.23)$. However, male staying at home $(M=11.66)$ were found to lack purpose than the female counterparts at home $(M=10.01)$. The explanation here may be the unintended negative impact of peer influence on the emotional state-of-mind of medical students, the effects of peers on the quantity of time devoted to studying, travelling long distances to class, feelings of personal life disrupting studies, high workload and even latter-day demotivational factors such as social networking which have been found to diminish academic performance $(18,9)$. This study does not highlight the factors creating this dissonance and warrants further investigation. Another possibility is that the demand of the curriculum and disorganisation disrupts the students' sense of purpose and students have difficulty making sense of their programme (19).

As revealed in data analysis, nursing students scored significantly better than students from one or more groups (medicine, dentistry, pharmacy and veterinary) in the subscales "seeking meaning" and "use of evidence", and subsequently leading to better scores in "deep approach". The nursing students also scored higher in "time management" and "monitoring effectiveness". The nursing 
cohort is predominantly an intake of mature students with existing practical skills, better prepared for tertiary education, factors which make the findings predictable and consistent with studies (44), (18). The authors reported that distinct generational approaches to study and learning and posit that age and good problem-solving skills are associated with a deep approach to learning. Meeks et al. (44) explored learning approaches across three generations: Baby Boomers, Generation Xers and Millennials and found that the older generation displays strong tendencies for deep approaches to learning. While the intergenerational tags are not applied in this research there is consistency with the hypothesis tested and the results.

Pharmacy students significantly scored higher in subscales "alertness to assessment demands", "achieving", "strategic approach", "unrelated memorising", "surface apathetic approach", and "lack of purpose" than any other subgroups. The students registered in veterinary program display "fear of failure" and is also second group after pharmacy in the subscale "surface apathetic approach". Previous factor analyses of veterinary students' enrolled into programmes straight out of secondary school (as opposed to previous degree holders) reveal surface learning approaches underscored by syllabus-boundness, fear of failure, grades and negative perceptions of the workload (20). Research studies consistently link content overload to surface learning and that veterinary students feel constrained from pursuing a deep approach due to their perception of the course workload $(18,20)$.

The study has a number of limitations. Learning styles were assessed using only one instrument and their relationship with the academic performance of the students was not investigated. Though, the study was conducted with the students of five health related schools in the Faculty of Medical Sciences, the findings should be applied to other settings in the Caribbean with caution.

\section{CONCLUSION}

The findings of the present study demonstrated that medical sciences students from different schools used varied approaches to their study and understanding of learning. Overall, students from all the schools mainly adopted strategic and deep approaches, and students from nursing and medical schools preferred deep approach than their counterpart in other schools. Students with a deep approach usually achieve a higher academic performance and motivating students towards a deep approach should be main aim of the medical science curricula. Thus to encourage better study approaches that will promote deep and strategic learning necessary orientation and mechanism should be in place for students. Further studies of learning styles in other medical schools in the Caribbean are required to examine whether there are specific benefits to particular styles for certain disciplines.

\section{REFERENCES}

1. Yip MC. Differences in learning and study strategies between high and low achieving university students: a Hong Kong study. Educ Psychol. 2007;27(5):597-606. https:// doi.org/10.1080/01443410701309126.

2. Credé M, Kuncel NR. Study habits, skills, and attitudes: the third pillar supporting collegiate academic performance. Perspect Psychol Sci. 2008;3(6):425-53. https://doi. org/10.1111/j.1745-6924.2008.00089.x.

3. Azikiwe U. Study approaches of university students. WCCI Region II Forum. 1998;2:106-14.

4. Chessell G. Learning styles in first year medical students. Med Teach. 1986;8(2):125-35. https://doi.org/10.3109/ 01421598609010738 . 
5. Parpala A, Lindblom-Ylänne S, Komulainen E, Litmanen T, Hirsto L. Students' approaches to learning and their experiences of the teaching-learning environment in different disciplines. $\mathrm{Br} \mathrm{J}$ Educ Psychol. 2010;269-82. https://doi. org/10.1348/000709909X476946.

6. Reid W, Evans P, Duvall E. Medical students' approaches to learning over a full degree programme. Med Educ Online. 2012;17(1):17205. https://doi.org/10.3402/ meo.v17i0.17205.

7. McManus IC, Richards P, Winder BC, Sproston KA. Clinical experience, performance in final examinations, and learning style in medical students: prospective study. BMJ. 1998; 316(7128):345-50. https://doi.org/10.1136/ bmj.316.7128.345.

8. McNulty JA, Ensminger DC, Hoyt AE, Chandrasekhar AJ, Gruener G, Espiritu B. Study strategies are associated with performance in basic science courses in the medical curriculum. J Educ Learn. 2012;1(1):1-12. https://doi.org/10.5539/jel. $\mathrm{v} \ln 1 \mathrm{p} 1$.

9. Al Shawwa L, Abulaban AA, Abulaban AA, Merdad A, Baghlaf S, Algethami A, Abushanab J, Balkhoyor A. Factors potentially influencing academic performance among medical students. Adv Med Educ Pract. 2015;6:65-75.

10. Amin Z, Tani M, Hoon Eng K, Samarasekara DD, Huak CY. Motivation, study habits, and expectations of medical students in Singapore. Med Teach. 2009;31(12):e560-9. https://doi. org/10.3109/01421590903193554.

11. Didarloo A, Khalkhali HR. Assessing study skills among a sample of university students: an Iranian survey. J Educ Eval Health Prof. 2014;11:8.
12. Liew SC, Sidhu J, Barua A. The relationship between learning preferences (styles and approaches) and learning outcomes among pre-clinical undergraduate medical students. BMC Med Educ. 2015;15(1):44. https://doi. org/10.1186/s12909-015-0327-0.

13. Tait H, Entwistle NJ, McCune V. ASSIST: a reconceptualisation of the approaches to studying inventory. In: Rust C, editor. Improving students as learners. Oxford: Oxford Brookes University, The Oxford Centre for Staff and Learning Development; 1984. p. 262-71.

14. Fleming N, Mills C. VARK: a guide to learning styles [Internet]. New Zealand: VARK Learn Ltd; c2017 [cited March 2016]. Available from: http://www.vark-learn. com.

15. Zeegers P. Approaches to learning in science: a longitudinal study. $\mathrm{Br} \mathrm{J}$ Educ Psychol. 2001;71(1):115-32. https://doi. org/10.1348/000709901158424.

16. Vermunt JD. Inventory of learning styles in higher education. Maastricht: Maastricht University; 1994.

17. Gujjar AA, Bajwa NU, Ramzan M. A comparative study of the study habits of the students of the Islamia University of Bahawalpur in Pakistan. Lang India. 2011;11(1):27-49.

18. Chigerwe M, Ilkiw JE, Boudreaux KA. Influence of a veterinary curriculum on the approaches and study skills of veterinary medical students. J Vet Med Educ. 2011;38(4):384-94. https://doi.org/10.3138/ jvme.38.4.384.

19. Ruohoniemi M, Parpala A, LindblomYlänne S, Katajavuori N. Relationships between students' approaches to learning, perceptions of the teaching-learning environment, and study success: a case study of third-year veterinary students. J Vet Med Educ. 2010;37(3):282-8. https://doi. org/10.3138/jvme.37.3.282. 
20. Ryan MT, Irwin JA, Bannon FJ, Mulholland CW, Baird AW. Observations of veterinary medicine students' approaches to study in pre-clinical years. J Vet Med Educ. 2004;31(3):242-54. https://doi.org/10.3138/ jvme.31.3.242.

21. Rawlins J, Sa B, Brathwaite R. Measuring medical students' sense of preparedness for community visits to antenatal patients in the health centre setting in Trinidad. J Public Health. 2013;21(4):349-56. https://doi. org/10.1007/s10389-013-0560-0.

22. Entwistle N, Waterston S. Approaches to studying and levels of processing in university students. $\mathrm{Br} \mathrm{J}$ Educ Psychol. 1988;58(3):258-65. https://doi. org/10.1111/j.2044-8279.1988.tb00901.x.

23. Lawal J, Weaver S, Bryan V, Lindo JL. Factors that influence the clinical learning experience of nursing students at a Caribbean School of Nursing. J Nurs Educ Pract. 2016;6(4):32-9.

24. Majumder MA. How can we teach students if we do not know how they learn? South Asia J Public Health. 2013;3:70-3.

25. Romanelli F, Bird E, Ryan M. Learning styles: a review of theory, application, and best practices. Am J Pharm Educ. 2009;73(1):9. https://doi.org/10.5688/ aj730109.

26. Leite WL, Svinicki M, Shi Y. Attempted validation of the scores of the VARK: learning styles inventory with multitraitmultimethod confirmatory factor analysis models. Educ Psychol Meas. 2010;70(2):323-39. https://doi.org/10.1177/ 0013164409344507.

27. Prosser M, Trigwell K. Understanding learning and teaching: the experience in higher education. Buckingham: The Society for Research into Higher Education and Open University Press; 1999.

28. Biggs JB. Student approaches to learning and studying. Hawthorn: Victoria: Australian Council for Educational Research; 1987.
29. Kleijn WC, van der Ploeg HM, Topman RM. Cognition, study habits, test anxiety, and academic performance. Psychol Rep. 1994;75(3):1219-26. https://doi. org/10.2466/pr0.1994.75.3.1219.

30. Newble DI, Hejka EJ, Whelan G. The approaches to learning of specialist physicians. Med Educ. 1990;24(2):101-9. https://doi.org/10.1111/j.1365-2923.1990. tb02507.x.

31. Chung EK, Elliott D, Fisher D, May W. A comparison of medical students' learning approaches between the first and fourth years. South Med J. 2015;108(4):207$10 . \quad$ https://doi.org/10.14423/ SMJ.0000000000000260.

32. Jayawardena CK, Hewapathirana TN, Banneheka S, Ariyasinghe S, Ihalagedara D. Association of learning approaches with academic performance of Sri Lankan firstyear dental students. Teach Learn Med. 2013;25(4):334-41. https://doi.org/10.1080/ 10401334.2013 .827978 .

33. Rochmawati E, Rahayu GR, Kumara A. Educational environment and approaches to learning of undergraduate nursing students in an Indonesian School of Nursing. Nurse Educ Pract. 2014;14(6):729-33. https://doi. org/10.1016/j.nepr.2014.08.009.

34. Varunki M, Katajavuori N, Postareff L. First-year students' approaches to learning, and factors related to change or stability in their deep approach during a pharmacy course. Stud High Educ. 2017;42(2):33153. https://doi.org/10.1080/03075079.2015. 1049140.

35. Foster PS, Gaughf NW. Pilot study of the study behavior inventory: preliminary analysis of a new tool for health science education students. J Contemp Med Educ. 2014;2:237-9. https://doi.org/10.5455/jcme. 20140911043437. 
36. Shankar PR, Balasubramanium R, Dwivedi NR. Approach to learning of medical students in a Caribbean Medical School. Educ Med J. 2014;6(2):e33-40. https://doi. org/10.5959/eimj.v6i2.235.

37. Wilson JI. A two factor model of performance approach goals in student motivation for starting medical school. Issues in Educ Res. 2009;19(3):271-81.

38. Martin H, Lewis T, Edwards K. Leadership, learning styles and academic performance of undergraduate engineering students in Trinidad. World Eng Educ. 2011;14:359-64.

39. General Medical Council. Tomorrow's doctors: recommendations on undergraduate medical curriculum. London: General Medical Council; 1993.

40. Newble DI, Entwistle NJ. Learning styles and approaches: implications for medical education. Med Educ. 1986;20(3):162-75. https://doi.org/10.1111/j.1365-2923.1986. tb01163.x.
41. Norman GR, Schmidt HG. The psychological basis of problem-based learning: a review of the evidence. Acad Med. 1992;67(9):557-65. https://doi.org/ 10.1097/00001888-199209000-00002.

42. May W, Chung EK, Elliott D, Fisher D. The relationship between medical students' learning approaches and performance on a summative high-stakes clinical performance examination. Med Teach. 2012;34(4):e23641. https://doi.org/10.3109/0142159X.2012. 652995.

43. Desforges C, Abouchaar A. The impact of parental involvement, parental support and family education on pupil achievements and adjustment: a literature review. Nottingham: DfES Publications; 2003.

44. Meeks MD, Williams F, Knotts TL, James KD, Darney C, Howcroft G, Stroud L, Ahmad R, Yei ET, Bujang S, Olayiwola IO. Deep vs. surface learning: an empirical test of generational differences. Int J Educ Res. 2013;1(8):1-5. 